\title{
SEARCHING FOR NON-LINEAR EFFECTS OF FISCAL POLICY: EVIDENCE FROM INDUSTRIAL AND DEVELOPING COUNTRIES
}

\author{
Francesco Giavazzi \\ Tullio Jappelli \\ Marco Pagano \\ Working Paper 7460 \\ http://www.nber.org/papers/w7460 \\ NATIONAL BUREAU OF ECONOMIC RESEARCH \\ 1050 Massachusetts Avenue \\ Cambridge, MA 02138 \\ January 2000
}

We thank Alberto Alesina, Zvi Eckstein, Harald Uhlig, an anonymous referee and seminar participants at the ISOM Conference for helpful comments. The Training and Mobility of Researchers Network Program (TMR) of the European Commission DGXII, the Italian National Research Council (CNR), the Ministry of University and Scientific Research (MURST) and Bocconi University provided financial support. Giovanni Radicella and Luca Flabbi offered valuable research assistance. The views expressed herein are those of the authors and not necessarily those of the National Bureau of Economic Research.

(C) 2000 by Francesco Giavazzi, Tullio Jappelli, and Marco Pagano. All rights reserved. Short sections of text, not to exceed two paragraphs, may be quoted without explicit permission provided that full credit, including (C) notice, is given to the source. 
Searching for Non-Linear Effects of Fiscal Policy:

Evidence from Industrial and Developing Countries

Francesco Giavazzi, Tullio Jappelli, and Marco Pagano

NBER Working Paper No. 7460

January 2000

JEL No. E21, E62, H31

\section{ABSTRACT}

Several recent studies suggest that the response of national saving to fiscal policy may be nonlinear. In this paper we use two data sets to search for the circumstances in which such non-linear responses may arise: a sample of OECD countries, already used in previous studies, and sample of developing countries, using more recent World Bank data. We find that in both samples non-linear effects tend to be associated with large and persistent fiscal impulses. In the OECD sample the nonlinearity of the response is stronger for fiscal contractions than for expansions. An increase in net taxes has no effect on national saving during large fiscal contractions, while it has a positive effect in less pronounced contractions. High or rapidly growing public debt does not appear to be a good predictor of non-linear effects. In the World Bank sample of developing countries, non-linearities in the response national saving to fiscal policy are not limited to large fiscal contractions, and also tend to occur in periods in which debt is accumulating rapidly, regardless of its initial level.

Francesco Giavazzi

IGIER

Universita' Bocconi

5 , via Salasco

20136-Milan

Italy

and NBER

giavazzi@mit.edu

Marco Pagano

CSEF

Universita' di Salerno

mrpagano@tin.it
Tullio Jappelli

CSEF

Universita' di Salerno

tullioj@tin.it 


\section{Introduction}

Even though fiscal policy is a classic theme in macroeconomics, there is still no consensus about the size or even the sign of its effects on private sector behavior. The research which attempts to shed light on these issues has gained new impetus, also as a result of the astonishing consequences of two instances of sharp fiscal retrenchment that occurred in Denmark and Ireland in the 1980s. ${ }^{1}$ Both episodes, as well as the symmetric consequences of the Swedish fiscal expansion of the early 1990s, appear to contradict the conventional view that an increase in the government surplus is contractionary and raise two important questions. First, is there something peculiar to the Danish, Irish and Swedish experiences, or are there comparable episodes in other countries as well? If so, can one identify circumstances in which fiscal policy is more likely to have such non-conventional effects?

As we shall see in Section 2, expansionary fiscal contractions can be explained by the effects of fiscal policy on the market value of wealth and on expectations about future taxes. A fiscal contraction often reduces interest rates, raising the market value of stocks, bonds and real estate, thus stimulating aggregate demand. It can also drastically change people's view of the future and thus the valuation of their human capital. For instance, in a high-debt country, a fiscal correction may reduce the likelihood of public sector default, thus improving confidence and increasing consumption and investment.

Several empirical studies, reviewed in Section 3, have confirmed that expansionary fiscal contractions do indeed happen. It is still an open question, however, under which conditions a fiscal consolidation induces a boom or, conversely, a fiscal expansion brings about a recession. Perotti (1999) finds that the outcome of a consolidation is more likely to be expansionary when public debt is high or growing rapidly. Giavazzi and Pagano (1996) find that private sector behavior following a fiscal impulse depends on the size and persistence of the impulse. Alesina and Perotti (1995) and Alesina and Ardagna (1998) find that the composition of the fiscal

\footnotetext{
${ }^{1}$ In Denmark, between 1983 and 1986, a reduction in the full-employment surplus of 7.2 percent of GDP was accompanied by a boom in private consumption and investment. In Ireland, between 1987 and 1989, a similar cut in the full-employment surplus (5.7 percent of GDP) was also accompanied by higher growth. Shortly afterwards, in a symmetrical pattern, the Swedish fiscal expansion of the early 1990s was associated with a sharp contraction in economic activity.
} 
adjustment also matters: the private sector response may differ depending on whether the budget is cut by slashing public sector wages and reducing social security benefits, or by raising taxes and cutting public investment. The common finding of these studies is that the response of the private sector to fiscal policy may be non-linear: both the magnitude and the sign of the response appear to change depending on the conditions under which the impulse occurs and on its characteristics.

This paper conducts a systematic search to determine which factors are more likely to give rise to such non-linearities. We use two data sets. OECD data over the past thirty years contain a rich set of fiscal variables and allow comparison with previous work. The World Saving Data Base recently produced by the World Bank includes the most comparable panel of national accounts from developing countries. While not as accurate and complete as OECD data, they allow us to study a large number of still unexplored fiscal episodes and to compare the evidence from developing countries with that from industrial countries.

Studies of the effects of fiscal policy on private sector behavior have typically looked at consumption. ${ }^{2}$ This paper considers the problem from a slightly different angle: we investigate the private sector behavior during fiscal episodes by concentrating on national saving. Looking at national saving has the advantage of allowing us to compare our results directly with the predictions of the Ricardian equivalence proposition. As is well known, models with infinite horizons imply that, for given government spending, taxes and transfers have no effect on national saving, that is, the Ricardian proposition holds. The standard overlapping generations model predicts instead that an increase in taxes (or a reduction in transfers) raises national saving. Yet other models, which we shall review in Section 2, suggest that the sign and size of the effect of fiscal policy on national saving depend on the level and sustainability of government debt, the size and persistence of the fiscal impulse, and the change in composition of the budget. According to some of these models an increase in net taxes may even produce a decline in national saving, by generating a boom in private consumption.

2 An exception is the analysis of the response of private investment to a fiscal impulse provided by Alesina, Ardagna, Perotti and Schiantarelli (1999). 
The main results of our empirical analysis are presented in Section 4 for the OECD countries and in Section 5 for the World Saving Data Base. In our empirical specification the impact of fiscal policy on national saving can depend on: (i) the sign of the impulse (budget cut or expansion); (ii) its size and duration; (iii) the previous level or rate of growth of public debt; (iv) the composition of the impulse (changes in taxes and transfers relative to changes in government consumption, changes in public investment or in social security entitlements). Section 6 concludes.

\section{Competing Theories}

To begin, we outline the main competing hypotheses on the response of national saving to fiscal impulses. The models generally make predictions about private consumption. We map them into predictions about the response of national saving, to facilitate the interpretation of the regressions presented in Section 4, where national saving is the dependent variable. For simplicity, we consider closed-economy models.

Recall that, by accounting definitions, national saving is the difference between national income and the sum of private and public consumption:

$$
S=S_{G}+S_{P}=(T-G)+(Y-T-C)=Y-(C+G),
$$

where $S$ denotes national saving, $S_{G}$ government saving, $S_{P}$ private saving, $Y$ national income, $T$ taxes net of transfers and interest payments on the public debt (hereafter, net taxes) and $G$ government purchases of goods and services.

The predictions of the main hypotheses are summarized in Table 1. The predicted response of national saving to fiscal impulses differs greatly from model to model. The theories surveyed in this section help directing us to the variables associated with one or another of such responses. We shall use this information as a guide in our empirical search for the conditions under which a fiscal impulse can produce non-linear effects on national saving.

\section{[INSERT TABLE 1]}




\subsection{Taxes and Transfers}

In the standard IS-LM model, given public spending, an increase in taxes (or a cut in transfers) raises the government surplus and depresses private consumption and private saving. The increase in the government surplus may exceed or fall short of the fall in private saving, so that, on balance, higher net taxes have an ambiguous impact on national saving. ${ }^{3}$ Wealth effects on private consumption (as in Blinder and Solow, 1974) reinforce the negative impact of the tax increase on national saving. If the increase in the surplus reduces the interest rate - either via a traditional crowding-in mechanism or by reducing the default premium on public debt - the resulting appreciation of stocks, bonds and real estate can trigger a consumption boom and make the reduction in national saving more likely.

In full employment models with intertemporally optimizing households, the effect of an increase in net taxes on national saving depends on the planning horizon, on the distortionary effect of taxes and on expectations about future fiscal policy. The benchmark case is that of a lump-sum increase in net taxes where the additional revenue is used to retire public debt and reduce net taxes on future generations, holding the path of government consumption constant.

If households have a finite planning horizon, as in overlapping generations models with non-altruistic consumers, net lifetime income for the current generation falls, and households reduce their consumption and saving accordingly. The reduction in private saving, however, falls short of the increase in net taxes, as households spread the cut in consumption over their lifetime. The implied increase in the government surplus thus exceeds the fall in private saving, producing a positive correlation between net taxes and national saving.

If, instead, households have infinite horizons, one obtains the well-known neutrality result, often labeled as complete tax discounting or "Ricardian equivalence proposition". An increase in net taxes does not affect private consumption, because net lifetime income is unchanged: the reduction in current disposable income reduces private saving one-for-one. National saving is unaffected, because the fall in private saving precisely matches the rise in the government surplus.

\footnotetext{
${ }^{3}$ Since in a closed economy national savings equal investment, the ambiguity may be understood by considering what happens to private investment. Assume that investment depends positively on income and negatively on the interest rate. A tax increase shifts the IS curve inwards, resulting in a lower interest rate and income. The net effect on investment is ambiguous.
} 
If taxes are distortionary, this neutrality result no longer obtains, even in infinite horizon models. A net tax increase today, matched by lower taxes tomorrow, changes the deadweight cost of taxes at different dates and thereby affects the present value of pre-tax lifetime income and therefore private consumption. If households have infinite horizon, the effect is a decline in national saving. ${ }^{4}$

In some models, the presence of distortionary taxes can lead to non-linear effects of fiscal policy, as is illustrated by Blanchard (1990). He considers a model where households face a constant probability of death, and assumes that the deadweight cost of taxation is strongly nonlinear: it is zero until the tax rate reaches a critical threshold, positive and high above that. When the public debt-income ratio is low, an increase in net taxes increases national saving, as in standard finite horizon models (see above). If instead the debt-income ratio is high, the response of national saving can be negative. In this case, in fact, an increase in net taxes today diminishes the chances that the government will have to raise the tax rate above the critical level tomorrow. As a result, households revise upward their expected net lifetime income, and hence private consumption. From equation (1), this translates into lower national saving, because $Y$ stays constant (if the tax rate is below the critical threshold) and $G$ is given. ${ }^{5}$ The implication is that the impact of higher net taxes on national saving may switch from positive to negative when the debtincome ratio is high.

There are other cases in which tax policy can have a non-linear effect on national saving. For instance, assume that the current fiscal policy stance is unsustainable and if not corrected will

\footnotetext{
${ }^{4}$ Suppose that initially the overall tax burden is either efficiently smoothed over time or inefficiently concentrated in the current period. Then, an increase in current taxes reduces current income and, by a lesser extent, the lifetime income of households. So consumption falls by less than current income, in step with the lower lifetime income. Equation (1) then implies a lower national saving (recall that $G$ is constant). If instead initially the tax burden is inefficiently concentrated in future periods, an increase in current taxes reduces current income but increases lifetime income and consumption, and therefore reduces national saving. So in both cases the outcome is a fall in national saving, more pronounced in the second case.

${ }^{5}$ More generally, a tax hike may translate into lower national saving if the deadweight cost of taxes is an increasing function of the tax rate. This effect occurs when current taxes are inefficiently low relative to the future taxes required by the existing public debt and the path of public spending. If the government is raising relatively little tax revenue today, it is implicitly leaving most of the tax burden for the future, inefficiently imposing a very large deadweight cost on future production. Thus shifting part of this burden to the present represents efficient "tax smoothing" and can raise consumption.
} 
lead to public debt repudiation, disrupting the financial sector and the real economy. Raising net taxes lowers the probability of default and the associated output costs. The implied increase in expected net lifetime income raises current private consumption and reduces national saving. In this example the response of the private sector hinges on people's confidence on the switch to "sound finance". If the credibility of the regime shift is enhanced by the magnitude of the fiscal turnaround (as suggested by Feldstein, 1982) sufficiently large changes in current net taxes can switch the sign of the response of national saving. Even if a small increase in net taxes increases national saving, a large and persistent one can leave it unaffected or even reduce it.

Sutherland (1997) provides another model in which expectations can trigger such nonlinear responses. Suppose that consumers have finite planning horizons, so that increases in net taxes normally depress consumption and raise national saving. However, let consumers also expect that when the public debt-income ratio exceeds a given threshold, a major stabilization will occur. If the debt-income ratio is near the threshold, a tax increase delays reaching the threshold, and so delays the "day of reckoning", making the adjustment more likely to fall on the shoulders of future generations. Paradoxically, the tax increase raises the expected net lifetime income and the consumption of the current generation. So the positive effect of net taxes on national saving that occurs under normal circumstances is again attenuated or even reversed when public debt is high relative to income. ${ }^{6}$

\subsection{Government Consumption}

In the IS-LM model, higher government spending has an ambiguous impact on investment and national saving, just as a reduction in net taxes. An increase in $G$ raises income and interest rates. Since these variables affect investment in opposite directions, the impact on national saving is ambiguous.

In an infinite horizon model with complete tax discounting and no tax distortions, government consumption "crowds out" private consumption one for one: each dollar of extra government spending subtracts a dollar from permanent income and hence from consumption 
$(\Delta C=-\Delta G)$. For a given path of pre-tax income $Y$, from equation (1) we see that an increase in $G$ leaves national saving unchanged. This may not be true in the presence of distortionary taxes. Consider an increase in $G$ with current taxes staying unchanged. The increase in $G$ leads people to expect not only higher future taxes, but also a lower net lifetime income due to the future distortions. So their consumption will decrease by more than the increase in public spending, and national saving falls. Therefore, in an infinite horizon model, the effect of higher public consumption on national saving is nil or negative. ${ }^{7}$

The prediction of finite-horizon models is more clear-cut. Greater public consumption (whether funded by taxes or debt) reduces private saving. Since the effect on public saving is also negative, an increase in public consumption reduces national saving.

As shown in section 2.1 for the case of taxes, the effects of expectations can alter these predictions. Suppose that large increases in public spending are taken as the signal of a transition to a regime of higher permanent spending and therefore higher permanent taxes, while small increases are expected to be reversed in the future. A large increase in $G$ thus reduces private consumption and leaves national saving unchanged (in the benchmark case of complete tax discounting with no distortions). However, a small increase in $G$ does not affect private consumption but reduces the public surplus and national saving. This argument, proposed by Feldstein (1982) and Drazen (1990), suggests a potential source of non-linearity in the effect of government consumption on national saving.

Non-linearities driven by expectations can even lead to a switch in the sign of the relation between government consumption and national saving, as shown by Bertola and Drazen (1993). Suppose a fiscal stabilization is expected with some probability when public spending reaches a given threshold. ${ }^{8}$ Below the threshold, an increase in $G$ reduces private consumption less than one-for-one and therefore leads to a fall in national saving. But if $G$ keeps increasing even after

\footnotetext{
${ }^{6}$ Perotti (1999) also presents a model where tax shocks have a positive correlation with national saving in normal times and a negative correlation when the debt-income ratio reaches a threshold level, following a similar logic as in Blanchard (1990) and Sutherland (1997).

${ }^{7}$ The discussion in the text assumes that public spending has no effects on labor supply. If an increase in $G$ stimulates labor supply, as for example in Baxter and King (1993), investment and national saving will also increase.
} 
the threshold is reached, consumers, observing that the expected stabilization failed to materialize, will revise the estimates of their lifetime income and consumption sharply downward. This model accordingly predicts that the sign of the correlation between government consumption and national saving depends on the level of public spending relative to income.

Government consumption shocks have a non-linear effect on private consumption also in Perotti (1999), for reasons akin to those in Blanchard (1990). In Perotti's model, an increase in $G$ increases the consumption of liquidity-constrained households, and lowers that of unconstrained households, who see their net lifetime income reduced by the increase in future taxes and the implied distortions. The net effect on aggregate consumption is ambiguous: when the debtincome ratio is low, it is positive; when it is high, so are tax distortions, and aggregate consumption falls. As a result, the effect of an increase in $G$ on national saving is attenuated when the debt-income ratio is high.

\section{Previous Evidence and Empirical Strategy}

So far, empirical studies of unusual fiscal episodes have taken one of two approaches. Some distinguish the episodes on the basis of ex post criteria (e.g. the success of a fiscal contraction in reducing the debt-GDP ratio) and describe the characteristics of the fiscal impulse and the associated behavior of various endogenous variables (income growth, interest rates, or the exchange rate). These studies directly ask what makes a stabilization "successful", without addressing the intermediate question, namely how the private sector responds to a fiscal impulse. Other studies distinguish fiscal episodes on the basis of an ex ante criterion (e.g. the size or persistence of the fiscal stimulus) and then assess the effect of the government's action on endogenous variables, such as private consumption and investment.

The latter approach was prompted by the analysis of two fiscal policy episodes: the Danish stabilization of 1983-86, and the Irish stabilization of 1987-89. Giavazzi and Pagano (1990) conclude that in those episodes the size of the budgetary contraction was so large as to change

\footnotetext{
${ }^{8}$ The difference from the case discussed in Section 2.1 is that here the stabilization only occurs with some probability when the threshold is reached.
} 
expectations about future fiscal policy, and hence people's estimates of their net lifetime income. Further evidence in favor of the hypothesis of a non-linear response of private consumption to fiscal contractions - recessionary for small fiscal contractions, expansionary for large consolidations - is provided in Giavazzi and Pagano (1996), using a panel of OECD countries. That paper shows that the non-linearity applies to fiscal expansions as well. Large increases in the full-employment primary deficit dampen private consumption, while moderate ones produce the traditional Keynesian outcome. ${ }^{9}$ All these studies rely on the size and persistence of the change in the budget balance as the ex ante criterion determining the effects of fiscal policy on private consumption. ${ }^{10}$

Alesina and Perotti (1995, 1997), Alesina and Ardagna (1998) and the IMF (1996) take a different approach, by classifying the episodes according to their ex post performance. Alesina and Perotti define as "successful" those fiscal contractions which three years out produce a reduction of the debt-GDP ratio of at least 5 percentage points. According to their evidence, fiscal consolidations are more likely to stabilize the debt-GDP ratio when the budget improvement is obtained by cutting public wages and pension benefits. This result is consistent with the view that the effects of fiscal policy depend on how they affect expectations. Slashing these "untouchable" budget items, they argue, signals that a regime shift has occurred, thus stimulating output via a surge of optimism.

The IMF (1996), based on McDermott and Wescott (1996), defines "aggressive fiscal impulse" a tightening of the budget of at least 1.5 percentage points of GDP for at least 2 years. It terms "successful" those stabilizations that managed to reduce the debt-GDP ratio by at least 3 points within two years. Out of 63 "aggressive" fiscal contractions between 1970 and 1995, the 14 "successful" ones are associated with higher GDP growth, lower unemployment, lower real

\footnotetext{
${ }^{9}$ For early evidence on the role of the debt-GDP ratio in determining the effect of fiscal policy on consumption, see Nicoletti (1988).

${ }^{10}$ In a similar vein, the OECD (1996) investigates if similar results obtain with reference to output growth rather than consumption. The study identifies 15 episodes between 1974 and 1995 in which the cyclicallyadjusted surplus improves by at least 3 percentage points of GDP continuously over at least 2 consecutive years. It finds that fiscal consolidation did not uniformly lead to low growth, but the results are inconclusive: "overall there appears to be little relationship between either the extent or the pace of consolidation and growth rates during the process" (p. 39).
} 
interest rates and real exchange rate appreciation. This is further evidence that fiscal policy can have non-linear effects.

More recently, Alesina et al. (1999) have investigated the effects of fiscal impulses on private sector investment. They find that the composition of a fiscal retrenchment is a critical variable in determining the response of private investment, but fail to detect significant nonlinearities. Once one controls for the composition of the fiscal impulse, there is no evidence that private investment reacts differently during large fiscal adjustments than in normal times.

In this paper we analyze the relation between fiscal policy and national saving using ex ante criteria drawn from the theories surveyed in Section 2. We estimate a national saving regression interacting fiscal variables with a set of dummies that capture the various circumstances which, according to the various theories, may give rise to non-linearities: (i) a large and persistent fiscal impulse; (ii) a high debt-GDP ratio, and (iii) a rapidly growing debtGDP ratio.

For OECD countries, we define a "large and persistent fiscal impulse" as one in which the full employment surplus (as a percent of potential output) changes by at least 1.5 percentage points per year over a two-year period. This definition is similar to that used by Giavazzi and Pagano (1996) and the IMF (1996). We find 38 fiscal expansions and 65 fiscal contractions in the OECD sample. These are listed in the Appendix.

For the World Saving Data Base we lack estimates of the full-employment surplus, so a fiscal episode is defined as one in which the current surplus changes by at least 1.5 percent of current output per year over a two-year period. Based on this definition, we obtain 259 fiscal expansions and 270 fiscal contractions for developing countries. Since the threshold above which the change in surplus is defined to be "large and persistent" is somewhat arbitrary, we perform sensitivity analysis with respect to the definition of fiscal episodes both in the OECD and in the World Saving Data Base.

While the OECD data cover 18 industrial countries in the period 1970-1996, the World Saving Data Base contains yearly national income and fiscal variables for a group of 150 industrial and developing countries from 1960 to 1995 , adding up to some 5,000 observations. The data have been subject to extensive consistency checks, and thus represent an important 
improvement in terms of quality relative to other data sets. ${ }^{11}$ Due to missing observations on several variables and years, the sample we use includes only 101 developing countries over the period 1970-1994, although for several countries the sample size is actually shorter. We do not include in this sample the industrial countries present in the World Saving Data Base because for these countries we prefer to rely on the more detailed OECD data.

\section{Evidence from OECD Data}

Table 2 reports averages of selected macroeconomic variables before, during and after the episodes of sizable and persistent fiscal impulses that we identified in the OECD sample, separately for fiscal expansions and contractions. The figures suggest that the effects of fiscal policy may indeed be asymmetric and non-linear. For instance, real GDP and consumption growth decline, relative to their previous average, after fiscal expansions and contractions alike, but the average decline is sharper after the fiscal expansions than it is after the contractions. Real GDP and consumption growth are also higher during fiscal contractions than expansions. The gross national saving rate falls considerably following fiscal expansions (from 23.41 percent to 20.17 percent of potential output). Large fiscal contractions, on the contrary, increase gross national saving, although only slightly (from 21.91 to 22.66 percent). These descriptive statistics thus suggest the presence of asymmetries in the response of gross national saving to fiscal expansions and contractions. Finally, the table indicates that major fiscal consolidations have relied on increases in net taxes (i.e. on increases in taxes or reductions in transfers) rather than on spending cuts and that, by and large, they have managed to stabilize the debt-GDP ratio.

\section{[INSERT TABLE 2]}

To convey a visual impression of the correlations in the data, Figure 1 plots the first differences of the gross national saving rate and of the full-employment government surplus (both

\footnotetext{
${ }^{11}$ Full details on data sources are available in Loyaza et al. (1998). In the Appendix we report definitions and sources of the variables used in the estimation.
} 
are scaled by full-employment output, and differenced to purge them of country-specific variation). In the scatter diagram we draw a linear spline with knots set for values of the fullemployment surplus equal to -1.5 and 1.5 percent, the same thresholds used to identify large fiscal shocks in Table 2. The spline reveals a non-linear relationship between the two variables: the national saving rate is positively correlated with the full-employment surplus when the latter is below 1.5 percent of full-employment output, and is slightly negatively correlated with it for larger fiscal contractions. Interestingly, while the change in slope occurring at the 1.5 percent knot is large and statistically significant, that occurring at -1.5 percent is minuscule and not statistically different from zero. This suggests that the response of national saving to fiscal policy may indeed be non-linear, and that the non-linearity might only be present only for fiscal contractions. We thus turn to regression analysis to check if this purely descriptive evidence persists when conditioning for other factors affecting the national saving rate.

\section{[INSERT FIGURE 1]}

We estimate the following reduced-form equation which has the national saving rate (as a fraction of potential output) on the left-hand-side:

$$
\frac{S_{t}}{Y_{t}^{*}}=\alpha_{o}+\alpha_{1} \frac{S_{t-1}}{Y_{t-1}^{*}}+\alpha_{2} \frac{Y_{t}-Y_{t}^{*}}{Y_{t}^{*}}+\alpha_{3} r_{t}+\beta_{1} \frac{T_{t}}{Y_{t}^{*}}+\beta_{2} d \frac{T_{t}}{Y_{t}^{*}}+\gamma_{1} \frac{G_{t}}{Y_{t}^{*}}+\gamma_{2} d_{t} \frac{G_{t}}{Y_{t}^{*}}
$$

where $Y^{*}$ denotes potential output, ${ }^{12}\left(Y_{t}-Y_{t}^{*}\right) / Y_{t}^{*}$ the output gap and $r_{t}$ the real interest rate. The variable $d_{t}$ is a dummy for the circumstances in which fiscal policy can have non-linear effects according to the theories surveyed in Section 2. A more detailed description of this variable is provided below.

12 We scale national saving and fiscal variables by potential output to avoid problems of heteroskedasticity. Dividing by actual rather than potential output would introduce an endogeneity bias due to the correlation between the error term and the right-hand-side variables. It would also make it hard to relate the estimated coefficients to the theoretical predictions outlined in section 2, which are all stated in terms of levels of variables rather than ratios to current output. 
In equation (2), the lagged value of the national saving rate is expected to capture the dynamics of the dependent variable, while the output gap should reflect the response of private saving and of the government surplus to transitory changes in income. The (ex post) real interest rate is the difference between the short-term domestic rate and inflation, based on the private consumption deflator. Since the interest rate is potentially endogenous, we use its lagged value as instrument. Demographic variables (such as the proportion of the population less than 15 years old or greater than 65) were found to be not statistically significant, and are not included in the reported results. Even though we deal with a dynamic panel, the least squares within-group estimator is appropriate in our context. ${ }^{13}$

Our empirical specification can conveniently nest the various hypotheses laid out in Section 2. For instance, finite horizon models suggest that an increase in net taxes raises national saving $\left(\beta_{1}>0\right)$, whereas an increase in government consumption reduces it $\left(\gamma_{1}<0\right)$. In the infinite horizon model with lump-sum taxes, fiscal policy has no effect on national saving ( $\beta_{1}=0$ and $\left.\gamma_{1}=0\right)$. As highlighted in Table 1, in some circumstances, however, the private sector response to fiscal shocks can be dramatically altered by expectational mechanisms. To capture these circumstances, $T / Y^{*}$ and $G / Y^{*}$ are interacted with appropriately designed dummy variables $d$.

Several studies have estimated versions of equation (2) using time series data on individual countries, international cross-sections or panels (Modigliani, 1993; Masson, Bayoumi and Samiei, 1996). The main problem in estimating equation (2) is the potential endogeneity of the fiscal variables. Such endogeneity may arise from two different sources. Because of the automatic stabilizers built in the existing tax code, tax revenues and government transfers from and to the economy (which enter our definition of $T$ ) fluctuate with the business cycle, and are thus affected by the same shocks which affect national savings. ${ }^{14}$ We deal with this first source of

\footnotetext{
${ }^{13}$ Alvarez and Arellano (1999) establish the asymptotic properties of the within-group, LIML and GMM estimators for a first-order autoregressive model with individual effects when both $T$ and $N$ tend to infinity. They show that all three estimators are consistent when $T / N \rightarrow c$, with $0 \leq c \leq 2$, and that when $T$ $=N$ the three biases are equal. The intuitive reason is that in samples with relatively large $T$ (as in the case at hand) the simultaneity bias induced by the presence of the lagged dependent variable tends to zero.

${ }^{14}$ Government consumption, on the contrary, is unlikely to fluctuate systematically with the business cycle: fluctuations in unemployment, for instance, affect government transfers, but are unlikely to be correlated with government purchases of goods and services.
} 
endogeneity by instrumenting net taxes with the full-employment government surplus net of interest payments, as measured by the OECD.

The second potential source of endogeneity arises from the possibility that the country's fiscal rules themselves respond to the business cycle, which in standard models is positively correlated with national saving. ${ }^{15}$ For instance, suppose that in response to a negative income shock the government chooses to cut taxes more than implied by pre-existing tax rules, in order to stabilize output or smooth the tax burden. This implies that the measured full-employment surplus is positively correlated with output shocks, and therefore with the error of the saving regression. The estimated coefficient of net taxes, $\hat{\beta}_{1}$, will then exceed the true coefficient, $\beta_{1}$. The opposite bias would result if the government were to raise more taxes in response to a negative output shock, for instance because it targets a certain surplus-GDP ratio (say, to meet Maastricht-type criteria). Handling this potential bias is difficult in the extreme, although recently there have been attempts at constructing measures of exogenous fiscal policy shocks that are not based on the fullemployment surplus. Blanchard and Perotti (1999) identify tax and spending shocks in U.S. quarterly data by assuming that implementing fiscal policy changes requires at least one quarter and by relying on historical information on large discretionary changes in fiscal policy (such as the tax cut in the second quarter of 1975), in the same vein as Ramey and Shapiro's (1998) shocks in military spending. Fatàs and Mihov (1998) use standard VAR restrictions to identify government spending and revenue shocks in a sample of OECD countries. We shall discuss below, after presenting our estimates, how they may be affected by this second source of bias.

Column (1) of Table 3 presents the estimates of equation (2). The total number of observations in our sample (which includes 18 OECD economies over the period 1970 to 1996, with some unavailable observations) is 417 . Initially we do not interact the fiscal variables with the dummy variables $d$, so as to have a benchmark specification in which the effects of $G$ and $T$ are constrained to be linear. The lagged saving rate has a positive and significant coefficient, whose size (0.554) reveals a large degree of persistence. This implies that the long-run effects of

\footnotetext{
${ }^{15}$ In a Keynesian model, for instance, investment, and therefore national saving, is positively correlated with the business cycle. Similarly, in standard real business cycle models with optimizing agents, a
} 
the other saving determinants are approximately twice as large as the short-run effects reported in the table. The coefficient of the output gap is consistent with the effect predicted by the theory: private saving tends to increase and the government deficit tends to decrease in response to transitory increases in national income. ${ }^{16}$ The effect of a change in the real interest rate, which in principle is ambiguous, is not significantly different from zero at the 10 percent level. The coefficients of $T / Y^{*}$ and $G / Y^{*}$ are respectively positive (0.263) and negative (-0.735), and both are significantly different from zero at the 1 percent level. These results strongly contradict the infinite horizon model and are consistent with the predictions of finite horizon models. Given the continuing debate over the Ricardian equivalence proposition, the positive coefficient of net taxes is of interest in its own right. ${ }^{17}$

The other regressions in Table 3 test the hypothesis that the fiscal policy coefficients are stable. Our approach is to identify possible structural breaks in the relation between fiscal policy and national saving in the specific circumstances identified by the theories surveyed in Section 2, namely: (i) a protracted and sizable fiscal impulse, as defined in section 3; (ii) a high ratio of public debt to potential GDP; (iii) a rapidly growing ratio between gross debt and potential GDP. In each case we define an appropriate dummy variable. ${ }^{18}$

The results indicate that the effect of both $T / Y^{*}$ and $G / Y^{*}$ is highly non-linear. During "normal" times, the effect of net taxes on national saving remains positive $\left(\beta_{1}=0.496\right)$, but

positive transitory shock to productivity leads to higher private saving for reasons of intertemporal smoothing.

${ }^{16} \mathrm{We}$ also experimented with an alternative specification where a five-year moving average of the growth rate replaces the output gap among the regressors. This alternative specification is in line with the theoretical prediction of the life-cycle theory that past growth should have a positive effect on the national saving rate, as found in previous studies such as Modigliani (1993), Carroll and Weil (1994) and Jappelli and Pagano (1994). When we use this specification we also find that the coefficient of the lagged growth rate is positive and significant. All the other coefficients, however, are similar to those reported in Table 3.

${ }^{17}$ For instance, Bernheim (1987) concludes that the data do not support Ricardian equivalence, while Seater (1993) reaches the opposite conclusion.

${ }^{18} \mathrm{We}$ also experimented with a dummy that is equal to one if the effective exchange rate falls by more than 10 percent in the year preceding the fiscal impulse. According to the IS-LM model, a devaluation stimulates aggregate demand. Other things being equal, a devaluation should thus compensate the recessionary impact arising from a fiscal contraction and could thus modify the effects of fiscal policy shocks. However, the interaction terms between this dummy and fiscal variables were not significantly different from zero. For brevity, they are not reported. 
during sharp fiscal contractions or fiscal expansions, the effect is greatly attenuated $\left(\beta_{1}+\beta_{2}=0.496-0.307=0.189\right)$ although it remains statistically significant. In these episodes, the effect of government spending is also much smaller in absolute value $\left(\gamma_{1}+\gamma_{2}=-0.944+0.290=-\right.$ 0.654) than in normal times (as above, the sum of the two coefficients remains statistically significant.) Since the results may be sensitive to the values chosen to define a "sizable" change in the full-employment surplus, we also try raising the threshold from a fiscal correction of at least 1.5 percent over a two-year period to $2.0,2.5,3.0$, and 5.0 percent respectively. The results obtained are qualitatively similar, and for brevity they are not reported.

The non-linear response of the national saving rate to net taxes implied by these estimates may be affected by the second endogeneity bias discussed above. Suppose that the government reacts to large income shocks (though not to relatively smaller ones) by large discretionary changes in full-employment net taxes. If these discretionary changes in taxes are positive during large recessions, then the coefficient $\beta_{2}$ on the interacted tax variable will be under-estimated, while $\beta_{1}$ will not (because the government does not respond to small shocks with discretionary changes in taxes). Correspondingly, our results would indicate a non-linear response $\left(\hat{\beta}_{2}<0\right)$ while in fact there is none $\left(\beta_{2}=0\right)$. On the other hand, if the government were to respond to a large recession with a large reduction in full-employment taxes, the bias of $\hat{\beta}_{2}$ would go in the opposite direction, i.e. the estimated non-linearity in the response of national saving would be dampened.

In our sample, we find that the correlation between the full-employment surplus and the output gap is negative and significantly different from zero for small values of the gap $( \pm 2$ or 3 percent), and close to zero during strong expansions and deep recessions. This implies that $E\left(\hat{\beta}_{1}\right)<\beta_{1}$, but $E\left(\hat{\beta}_{2}\right)=\beta_{2}$, so that our estimated coefficients are unlikely to overestimate the non-linear response of national saving to net taxes.

In some of the models discussed in section 2 (for instance in Bertola and Drazen, 1990) the private sector's response may differ depending on the sign of the fiscal impulse. To test for this asymmetric behavior, we interact $T / Y^{*}$ and $G / Y^{*}$ with two separate dummies, one for large fiscal expansions and one for large fiscal contractions (the threshold is kept at the 1.5 percent 
level). In the regression reported in column (3) of Table 3 we find that the effect of fiscal policy differs between fiscal contractions and fiscal expansions. In particular, the effect of net taxes is positive (0.439) in "normal" times, smaller during large fiscal expansions $(0.219=0.439-0.220)$, and not statistically different from zero during large fiscal contractions $(0.034=0.439-0.405)$. The bottom line is that an increase in net taxes raises national saving, except during a sizable fiscal contraction, when the increase in private consumption fully offsets the positive effect of taxes on the government surplus. The pattern for government spending is similar. The coefficient is always negative, but its absolute value in normal times (-0.898) exceeds its value during sizable fiscal expansions $(-0.711=-0.898+0.187)$ and is almost twice as large as during sizable fiscal contractions $(-0.503=-0.898+0.395)$.

An intuitive way to understand this result is to plot the estimated impact of the government surplus on the national saving rate (both as ratios of potential output), for given government consumption. In normal times, this effect is equal to the product between the surplus and $\hat{\beta}_{1}$. During sizable fiscal contractions, this effect is supplemented by the interaction of the deficit with $\hat{\beta}_{2}$. To make the graph readable, this interactive effect is plotted only for fiscal contractions. (A similar decomposition could be performed for fiscal expansions, as well as for the effect of government consumption, for given deficit.)

In Figure 2 we use the coefficients estimated in column 3 to plot the national saving rate and the estimated short-run effects of the deficit in countries that have enacted the largest recent swings in fiscal policy: Sweden, Denmark, Ireland, and Belgium. We standardize the national saving rate by plotting deviations from the respective country's mean. Given the size of the coefficient of lagged saving, long-run effects are about twice as large as the short-run coefficients.

Consider first the effect of the deficit in Sweden, displayed in the upper-left corner of Figure 2. The line marked with diamonds is the national saving rate. The line marked with circles shows that in normal times the surplus increases national saving: the two lines move in the same directions. The line with crosses represents the total effect of the surplus. In normal times this coincides with the line marked with circles, while during large fiscal contractions it also includes the interaction term. In our sample period, Sweden had three large fiscal contractions (1983-84; 1986-88 and 1994-96). In each of these episodes the line with crosses virtually coincides with 
zero, indicating that the surplus has no effect on national saving. Similar considerations apply to the other three countries. In each of them, in normal times the surplus raises national saving, but the effect becomes close to zero during large fiscal contractions (in 1983-86 for Denmark; in 1977-78, 1983-85, 1987-89, and 1991-92 in Ireland; in 1974-75, 1981-87 and 1992-94 in Belgium). The figure clearly conveys the finding that the effect of the surplus on national saving is markedly non-linear.

\section{[INSERT FIGURE 2]}

According to some of the models outlined in section 2, the effect of fiscal policy can depend on the size of the public debt. In column (4) of Table 3 we interact taxes and spending with a dummy set equal to 1 if, during the year preceding the fiscal episode, gross public debt exceeds 70 percent of potential output. The coefficients of the interaction terms are small and not significantly different from zero, indicating that a high ratio of debt to potential output does not affect the impact of taxes and spending on national saving. Qualitatively similar results were obtained for other values of the debt ratio (such as 80 percent or 100 percent).

The sign and size of the response to fiscal impulses may also depend on the perceived sustainability of the fiscal regime. A regime may be perceived as "unsustainable" not only if the debt-income ratio is high, but also if it has been rising rapidly in the recent past. To capture such occurrences, we rely on the dummy for high debt growth computed and reported by Perotti (1999, Table 1, variable D3). The dummy equals 1 if the growth rate of the ratio of (cyclically adjusted) gross public debt to trend GDP exceeds 4 percent for two consecutive years, and 0 otherwise. The results are reported in column (5) of Table 3. The sign of the interaction terms is not consistent with a smaller fiscal impact on national saving in the wake of rapid debt accumulation.

The specifications in columns (3), (4) and (5) do not allow for possible interactions among the ex-ante criteria (size and persistence of the fiscal impulse, debt level and debt growth), which could be complementary sources of the non-linear response of national saving to fiscal policy. The natural next step, therefore, is to estimate a regression that includes all the interaction terms. The estimates obtained from this nested specification are displayed in column (6) of Table 3: they 
confirm that the main source of non-linearity is the size of the fiscal impulse, not the level or growth of public debt. Furthermore, the size and significance of the interaction terms are again stronger during contractions than during expansions.

On the whole, the results strongly support models in which increases in net taxes raise national saving, while increases in government spending reduce it (a non-Ricardian result). However, the effects of changes in taxes and spending are significantly dampened during large fiscal contractions. The dampening is particularly pronounced when the fiscal impulse comes on the side of net taxes. ${ }^{19}$ The evidence that these effects are related to a high or fast-growing debtincome ratio is weak at best.

We have also tried to investigate further the non-linear effects of fiscal policy. In particular, when sizable changes in fiscal policy occur, the non-linear effect of taxes and spending may depend on whether public debt is high or growing rapidly. Or it may depend on the composition of the fiscal impulse: the relative importance of tax hikes and cuts in government consumption, public investment, or pension transfers. We address these issues by interacting the dummy for "large fiscal contraction" and that for "large fiscal expansions" with dummy variables capturing episodes in which: (i) the ratio of public debt to potential output exceeds 70 percent, (ii) the average change in the ratio of debt to potential output exceeds 4 percent in two consecutive years, (iii) public investment is growing in real terms, (iv) social security benefits are reduced in real terms, or (v) the consolidation is effected by raising net taxes more than by cutting public consumption. The results, not reported for brevity, are inconclusive, because none of the additional interaction dummies is estimated with sufficient precision.

\section{Evidence from the World Saving Data Base}

In all of the empirical studies quoted above, as well as in this paper so far, the empirical evidence on possible non-linearities in the effects of fiscal policy has been limited to OECD countries. In

19 These results are broadly consistent with Giavazzi and Pagano (1996), which focuses on private consumption rather than national saving. 
this section we use the World Saving Data Base to test if in developing countries as well there is evidence of non-linearities in the effects of fiscal policy on national saving. As in the previous section, we look for asymmetries between fiscal expansions and fiscal contractions, and for the possibility that the level or the growth rate of the public debt affect the way in which national saving responds to a fiscal impulse. In doing this we keep the 70 percent threshold for the debtincome ratio, and a threshold of 4 percent for the change in the debt-income ratio in two consecutive years. ${ }^{20}$

Even if we try to replicate the regressions presented in Table 3 as closely as possible, there are differences in specification, definition of variables and estimation method that make the results not immediately comparable with those obtained for the OECD countries. Regarding specification, we omit the real interest rate, whose inclusion would require dropping more than half of the sample, and add as a right-hand-side variable the dependency ratio, defined as the percent of individuals in the population younger than 15 or older than 65 .

The definition of variables also differs from the OECD data set. Potential output, which is used to scale the variables, is not available in the World Saving Data Base: we constructed an estimate of this variable running individual country regressions of log output on a quadratic time trend. ${ }^{21}$ Furthermore, fiscal variables refer to the central government only, instead of the general government used for the OECD countries (data for local administrations, government agencies and public enterprises are only available for a much smaller set of countries).

Finally, concerning estimation, we use an OLS fixed effect estimator rather than instrumental variables. We could not use the lagged full-employment surplus as instrument, since

\footnotetext{
${ }^{20}$ Lopez, Schmidt-Hebbel and Servén (1998) review the mixed evidence on Ricardian equivalence in developing countries using a subset of the countries included in the World Saving Data Base. They estimate the impact of permanent and transitory fiscal policy shocks on consumption. Overall, their results represent strong rejection of Ricardian equivalence, particularly in the sample of developing countries. Loyaza, Schmidt-Hebbel and Servén (1998) and Schmidt-Hebbel and Servén (1999) exploit the full sample to investigate the main factors explaining the international variability in saving rates. They find that the growth rate of income, the age structure of the population and the government surplus are among the most important determinants of national saving rates.

${ }^{21}$ In several countries output fluctuations in the last three decades are quite large, so that a linear trend is a very bad approximation of potential output. We experimented using a sub-sample limited to 1980-04 and, on this sub-sample, estimated potential output by individual country regressions of log output on a linear time trend. The results are qualitatively unaffected.
} 
this variable is not available in the data set. Moreover, lagged variables are poor predictors of current taxes and of the interaction terms in the first-stage regressions. ${ }^{22}$ The limitations of this data set thus make the endogeneity problem much more difficult to tackle: in particular, we cannot claim that both our estimated coefficient of taxes, $\hat{\beta}_{1}$ and $\hat{\beta}_{2}$, are unbiased.

Attanasio, Picci and Scorcu (1998), using the same data, focus on the correlation between saving, growth and investment. They find that growth Granger-causes saving, with a positive sign, and uncover no compelling evidence that saving causes growth, a fact that is consistent with our saving specification. They also analyze carefully the estimation strategy in panels in which both the number of countries and the number of time periods are relatively large. In particular, comparison with a GMM estimator and with an estimator that allows for parameter heterogeneity and the results of a Monte Carlo experiment reveal that in the dynamic panel we are using the OLS bias is very small.

Our results are shown in Table 4. In the baseline specification, reported in column 1, the size of the coefficient of the lagged saving rate and the effect of the growth rate of income are similar to those obtained in the OECD sample. The negative coefficient of the dependency ratio is consistent with standard life-cycle models of consumption. The coefficients of net taxes and government spending reject Ricardian equivalence.

When we allow (column 2) for a different response of national saving to fiscal variables during episodes of large changes in the budget surplus, we find evidence of a non-linear effect for both taxes and government spending, as in the OECD sample. In this case, however, the offsetting effect of the interaction terms is slightly weaker for fiscal contractions than for expansions, as shown in column 3, where we allow for asymmetries between the two. Here, all the relevant coefficients are statistically significant at the 1 percent level, and the effect of taxes is positive in normal times (0.447), smaller during large fiscal contractions $(0.279=0.447-0.168)$ and even smaller during large fiscal expansions $(0.190=0.447-0.257)$.

The pattern for government spending is also similar to our previous findings, but again,

\footnotetext{
${ }^{22}$ These problems appear to be especially severe in the sub-sample for Latin American countries. When the observations for these countries are excluded from the sample, lagged taxes have predictive power for
} 
compared with the OECD sample, there is greater symmetry between the effects of large fiscal contractions and expansions. The coefficient of government spending is always negative, and its absolute value in normal times (-0.691) is larger than during both sizable fiscal contractions ($0.459=-0.691+0.232)$ and expansions $(-0.427=-0.691+0.264)$.

Overall these results, obtained from a much larger data set and in spite of the differences in data definitions, are consistent with our findings from the OECD regressions. The main difference regards the comparison between episodes of sizable expansions and contractions. While in Table 3 we found larger effects during fiscal contractions, here the non-linear effects occurring during large fiscal contractions and expansions are both important and rather symmetric. Due to data limitations, however, we cannot claim that the estimates for developing countries are unaffected by endogeneity bias.

In the regressions reported in columns (4) and (5) we introduce the dummies that identify situations where the fiscal action takes place in an environment of high (column 4) or rapidly accumulating (column 5) public debt. Recall that in the OECD regressions we found no evidence of a smaller impact of fiscal policy on national savings when the public debt is high, or growing rapidly. In the World Saving Data Base, we find instead that during periods of rapidly growing public debt (recall that we are using a threshold of 4 percent for the change in the debt-income ratio in two consecutive years preceding the fiscal episode) the impact of taxes and government spending on national savings is significantly different. In such situations, the effect of an increase in taxes on national saving is completely offset: the total effect is $-0.040=0.261-0.301$. The coefficient on government spending remains negative, but is significantly lower than in normal times $(-0.245=-0.497+0.252)$.

Finally, in column (6) we interact all the variables that could give rise to non-linearities in the response of savings to a fiscal impulse. The results confirm that the response of savings to an increase in taxes is significantly dampened during episodes of large budgetary contractions and expansions, and in situations when the debt-income ratio is growing fast, regardless of its level. The same holds, symmetrically, for the response of savings to government spending.

current taxes. The IV estimates that we obtain excluding Latin America are qualitatively similar to those presented in Table 4, although several coefficients are less precisely estimated. 
As already mentioned, the World Saving Data Base does not contain information on cyclically-adjusted fiscal variables. It is therefore possible that some of the episodes we identify are simply the result of the endogenous response of the budget to the cycle. One way to address this issue is by raising the threshold used to define a fiscal episode. In Table 5 we report the results obtained using two different definitions of a "large and persistent fiscal episode": those in which the full employment surplus changes by at least 2.5 or 5 percent per year over a two-year period. (Recall that in Table 4 we had identified fiscal episodes using a threshold of 1.5 percent, which gave us 259 expansions and 270 contractions.) When the limit is set at 2.5 percent there are 191 fiscal expansions and 222 contractions; these change to 108 and 128, respectively, when the limit is 5 percent. The general pattern of the results reported in Table 5 does not appear to be qualitatively affected: the absolute size of the coefficient estimates falls as we raise the threshold, in particular for net taxes and spending during large fiscal contractions, but the magnitudes of the standard errors remains virtually unchanged.

\section{Conclusions}

In this paper we have searched systematically for the circumstances in which national saving responds non-linearly to fiscal policy impulses. The evidence confirms some previous findings and complements them with a few new ones.

The data drawn from the OECD countries confirm that a non-linear response by the private sector is more likely when fiscal impulses are large and persistent. The finding that only sizable and persistent fiscal impulses trigger non-linear responses can be explained by models of regime changes: only large and politically costly fiscal actions can signal a regime change, and thus have a non-linear impact on private sector expectations and behavior. Non-linear effects are larger and more precisely estimated for changes in net taxes than for changes in public consumption. Non-linear responses also appear to be asymmetric, stronger and more precisely estimated for fiscal contractions than for fiscal expansions; in particular, during large fiscal contractions an increase in net taxes has little or no effect on national saving. In contrast with many of the relevant theoretical models, as well as with the evidence in Perotti (1999), we find 
that high or rapidly growing public debt is not per se a good predictor of these non-linear responses.

In the World Saving Data Base the situations in which the response of national saving is non-linear appear to be more frequent. In fact, they occur not only in the case of large fiscal contractions, but also in that of large fiscal expansions, and whenever a country is accumulating public debt rapidly, regardless of its initial level. These results for developing countries are novel and interesting, but more work needs to be done to overcome the limitations imposed by the data.

\section{References}

Alesina, Alberto and Silvia Ardagna (1998), “Tales of Fiscal Contractions,” Economic Policy 27.

Alesina, Alberto and Roberto Perotti (1995), "Fiscal Expansions and Adjustments in OECD Countries," Economic Policy 21, 205-248.

Alesina, Alberto and Roberto Perotti (1997), "Fiscal Adjustments in OECD Countries: Composition and Macroeconomic Effects," International Monetary Fund Staff Papers 44, 210-48.

Alesina, Alberto, Silvia Ardagna, Roberto Perotti and Fabio Schiantarelli (1999) "Fiscal Policy, Profits and Investment," NBER working paper n.7207.

Alvarez, Javier and Manuel Arellano (1999), "The Time Series and Cross-Section Asymptotics of Dynamic Panel Data Estimators," Journal of Econometrics, forthcoming.

Attanasio, Orazio P., Lucio Picci and Antonello Scorcu (1998), "Saving, Growth and Investment: A Macroeconomic Analysis Using a Panel of Countries," available at http://www.worldbank.org/research/projects/savings/policies.htm

Baxter, Marianne, and Robert King (1993), "Fiscal Policy in General Equilibrium," American Economic Review 83(3), 315-334.

Bernheim, Douglas (1987). "Ricardian Equivalence: an Evaluation of Theory and Evidence," NBER Macroeconomics Annual 2, 263-304.

Bertola, Giuseppe and Allan Drazen (1993), "Trigger Points and Budget Cuts: Explaining the Effects of Fiscal Austerity," American Economic Review 83, 1170-88. 
Blanchard, Olivier (1990), “Comment,” NBER Macroeconomics Annual 5, 111-116.

Blanchard, Olivier and Roberto Perotti (1999), "An empirical characterization of the dynamic effects of changes in government spending and taxes on output," NBER Working Paper n. 7269.

Blinder, Alan S. and Robert M. Solow (1974), "Analytical Foundations of Fiscal Policy," in The Economics of Public Finance, Washington, D.C.: The Brooking Institution.

Carroll, Christopher, and David Weil (1995), "Saving and Growth: a Reinterpretation," Carnegie Rochester Conference Series on Public Policies 40, 133-193.

Drazen, Allan (1990), “Comment,” NBER Macroeconomics Annual 5, 117-122.

Fatàs, Antonio, and Ilian Mihov (1999), "Measuring the effects of fiscal policy," INSEAD, mimeo.

Feldstein, Martin (1982), "Government Deficits and Aggregate Demand," Journal of Monetary Economics 9, 1-20.

Giavazzi, Francesco and Marco Pagano (1990), "Can Severe Fiscal Contractions be Expansionary? Tales of Two Small European Countries," NBER Macroeconomics Annual $5,75-111$.

Giavazzi, Francesco and Marco Pagano (1996), "Non-Keynesian Effects of Fiscal Policy Changes: International Evidence and the Swedish Experience," Swedish Economic Policy Review, May, 75-111.

IMF (1996), "Fiscal Challenges Facing Industrial Countries," World Economic Outlook, Chapter III. Washington: International Monetary Fund.

Jappelli, Tullio and Marco Pagano (1994), "Saving, Growth and Liquidity Constraints," Quarterly Journal of Economics 106, 83-109.

Loyaza, Norman, Humberto J. Lopez, Klaus Schmidt-Hebbel, and Luis Servén (1998), "The World Saving Data Base," available at http://www.worldbank.org/research/projects/savings/policies.htm

Lopez, Humberto J., Klaus Schmidt-Hebbel, and Luis Servén (1998), "How Effective is Fiscal Policy in Raising National Saving?," available at http://www.worldbank.org/research/projects/savings/policies.htm 
Masson, Paul R. Tamim Bayoumi and Hossein Samiei (1996), "International Evidence on the Determinants of Saving," CEPR Discussion Paper n. 1368, March.

McDermott, C. John and Robert F. Wescott (1996), "An Empirical Analysis of Fiscal Adjustment," International Monetary Fund Staff Papers 43, 725-53.

Modigliani, Franco (1993), "Recent Declines in the Savings Rate: A Life Cycle Perspective," in World Saving, Prosperity and Growth, Mario Baldassarri ed. New York: St. Martin Press.

Nicoletti, Giuseppe (1988), "Private Consumption, Inflation and the 'Debt Neutrality Hypothesis': The Case of Eight OECD Countries," OECD Working Papers n. 50, Department of Economics and Statistics, January.

OECD (1996), "The experience with fiscal consolidation with OECD countries," Economic Outlook 59, June, 33-41.

Perotti, Roberto (1996), "Fiscal Consolidation in Europe: Composition Matters," American Economic Review, Papers and Proceedings 86(2), 105-110.

Perotti, Roberto (1999), "Fiscal Policy When Things are Going Badly," Quarterly Journal of Economics, forthcoming.

Ramey, Valerie A. and Matthew D. Shapiro (1998), "Costly Capital Reallocation and the Effects of Government Spending," Carnegie Rochester Conference Series on Public Policy 48, 145-194.

Schmidt-Hebbel, Klaus, and Luis Servén (1999), The Economics of Saving and Growth. Cambridge: Cambridge University Press.

Seater, John (1993), “Ricardian Equivalence,” Journal of Economic Literature 31, 142-90.

Sutherland, Alan (1997), "Fiscal Crises and Aggregate Demand: Can High Public Debt Reverse the Effects of Fiscal Policy?," Journal of Public Economics 65. 
Table 1

Predicted Effects of a Fiscal Impulse on National Saving in Various Models

\begin{tabular}{|c|c|c|}
\hline Model & $\begin{array}{c}\text { Increase in net taxes } \\
\text { (given government consumption) }\end{array}$ & $\begin{array}{l}\text { Increase in government } \\
\text { consumption } \\
\text { (given net taxes) }\end{array}$ \\
\hline IS-LM & uncertain & uncertain \\
\hline Finite horizon & positive & negative \\
\hline $\begin{array}{l}\text { Infinite horizon and } \\
\text { non-distortionary taxes }\end{array}$ & no effect & no effect \\
\hline $\begin{array}{l}\text { Infinite horizon and } \\
\text { distortionary taxes }\end{array}$ & negative & negative \\
\hline $\begin{array}{l}\text { Blanchard (1990) } \\
\text { Sutherland (1995) }\end{array}$ & $\begin{array}{l}\text { depends on debt-income ratio: } \\
\text { positive if debt is low is small, } \\
\text { negative otherwise }\end{array}$ & \\
\hline $\begin{array}{l}\text { Drazen (1990) } \\
\text { Feldstein (1982) }\end{array}$ & $\begin{array}{l}\text { depends on the size of tax increase: } \\
\text { positive if the tax increase is small, } \\
\text { attenuated or negative otherwise }\end{array}$ & $\begin{array}{l}\text { depends on the size of the } \\
\text { increase in } G \text { : negative if the } \\
\text { increase is small, no effect for } \\
\text { large increases }\end{array}$ \\
\hline $\begin{array}{l}\text { Bertola and Drazen } \\
\text { (1993) }\end{array}$ & & $\begin{array}{l}\text { depends on } G / Y \text { : negative if the } \\
\text { ratio is small, positive otherwise; } \\
\text { non-linearity applies only to fiscal } \\
\text { expansions }\end{array}$ \\
\hline Perotti (1999) & $\begin{array}{l}\text { depends on the debt-income ratio: } \\
\text { positive if the ratio is small, } \\
\text { attenuated otherwise }\end{array}$ & $\begin{array}{l}\text { Depends on the debt-income } \\
\text { ratio: negative if the ratio is } \\
\text { small, attenuated otherwise }\end{array}$ \\
\hline
\end{tabular}




\section{Table 2}

\section{Episodes of Large and Persistent Fiscal Expansions and Contractions: Summary Statistics (OECD Countries: 1970-96)}

A large and persistent fiscal expansion or contraction is defined as an episode in which the ratio of full-employment surplus to potential output changes by more than 1.5 percent per year over a two-year period. Growth rates before (after) the episode are average growth rates of the relevant variables in the three years preceding (following) the start (end) of the episode. The ratio of gross public debt to potential output and the national saving rate before (after) the episode refer to one year before (after) the start (end). Due to missing values, the number of observations used to compute the averages in the table is in some case less than 38 for fiscal expansions and 65 for contractions.

\begin{tabular}{|c|c|c|}
\hline & Fiscal Expansions & Fiscal Contractions \\
\hline \multicolumn{3}{|c|}{ Growth rate of real GDP } \\
\hline Before & 2.57 & 2.21 \\
\hline During & 1.12 & 2.36 \\
\hline After & 2.00 & 2.13 \\
\hline \multicolumn{3}{|c|}{ Growth rate of real private consumption } \\
\hline Before & 2.43 & 2.38 \\
\hline During & 1.91 & 2.22 \\
\hline After & 1.71 & 2.29 \\
\hline \multicolumn{3}{|c|}{ Growth rate of real government consumption } \\
\hline Before & 3.64 & 3.48 \\
\hline During & 3.09 & 2.48 \\
\hline After & 1.86 & 2.94 \\
\hline \multicolumn{3}{|c|}{ Growth rate of real net taxes } \\
\hline Before & 4.39 & 2.71 \\
\hline During & 0.27 & 4.19 \\
\hline After & 3.40 & 2.25 \\
\hline \multicolumn{3}{|l|}{ Debt / potential output } \\
\hline Before & 48.01 & 56.63 \\
\hline During & 48.89 & 57.02 \\
\hline After & 55.66 & 56.29 \\
\hline \multicolumn{3}{|c|}{ National saving / potential output } \\
\hline Before & 23.41 & 21.91 \\
\hline During & 21.03 & 22.65 \\
\hline After & 20.17 & 22.66 \\
\hline Number of episodes & 38 & 65 \\
\hline
\end{tabular}


Table 3

\section{Effects of Fiscal Policy on National Saving: OECD Data}

The dependent variable is the ratio of national saving to potential output. The total number of observations is 417 . Instruments for net taxes and the real interest rate are the full-employment government surplus (scaled by potential output) and the lagged real interest rate. Countries included in the estimation and sample size are reported in the Appendix. All regressions are estimated with fixed effects. Standard errors are reported in parenthesis. The definition of the interaction terms is reported in the text.

\begin{tabular}{|c|c|c|c|c|c|c|}
\hline & (1) & $(2)$ & (3) & (4) & $(5)$ & $(6)$ \\
\hline Lagged national saving rate & $\begin{array}{c}0.554 \\
(0.037)\end{array}$ & $\begin{array}{c}0.562 \\
(0.038)\end{array}$ & $\begin{array}{c}0.627 \\
(0.042)\end{array}$ & $\begin{array}{c}0.549 \\
(0.037)\end{array}$ & $\begin{array}{c}0.554 \\
(0.037)\end{array}$ & $\begin{array}{c}0.614 \\
(0.046)\end{array}$ \\
\hline Output gap & $\begin{array}{c}0.249 \\
(0.037) \\
\end{array}$ & $\begin{array}{c}0.268 \\
(0.039) \\
\end{array}$ & $\begin{array}{c}0.293 \\
(0.040) \\
\end{array}$ & $\begin{array}{c}0.246 \\
(0.037) \\
\end{array}$ & $\begin{array}{c}0.239 \\
(0.038) \\
\end{array}$ & $\begin{array}{c}0.277 \\
(0.040) \\
\end{array}$ \\
\hline Real interest rate & $\begin{array}{c}0.063 \\
(0.022) \\
\end{array}$ & $\begin{array}{c}0.059 \\
(0.023) \\
\end{array}$ & $\begin{array}{c}0.044 \\
(0.024) \\
\end{array}$ & $\begin{array}{c}0.068 \\
(0.026) \\
\end{array}$ & $\begin{array}{c}0.064 \\
(0.025) \\
\end{array}$ & $\begin{array}{c}0.056 \\
(0.028) \\
\end{array}$ \\
\hline Net taxes $\left(\mathrm{T} / \mathrm{Y}^{*}\right)$ : & $\begin{array}{c}0.263 \\
(0.059) \\
\end{array}$ & $\begin{array}{c}0.496 \\
(0.108)\end{array}$ & $\begin{array}{c}0.439 \\
(0.110)\end{array}$ & $\begin{array}{c}0.272 \\
(0.058)\end{array}$ & $\begin{array}{c}0.278 \\
(0.063)\end{array}$ & $\begin{array}{c}0.471 \\
(0.119)\end{array}$ \\
\hline --- and large change in surplus & & $\begin{array}{c}-0.307 \\
(0.109)\end{array}$ & & & & \\
\hline --- and large increase in surplus & & & $\begin{array}{c}-0.405 \\
(0.118)\end{array}$ & & & $\begin{array}{c}-0.397 \\
(0.126)\end{array}$ \\
\hline --- and large decrease in surplus & & & $\begin{array}{c}-0.220 \\
(0.114)\end{array}$ & & & $\begin{array}{c}-0.224 \\
(0.122)\end{array}$ \\
\hline --- and high debt & & & & $\begin{array}{c}-0.015 \\
(0.082)\end{array}$ & & $\begin{array}{c}-0.014 \\
(0.203)\end{array}$ \\
\hline --- and rapid debt growth & & & & & $\begin{array}{c}0.066 \\
(0.214)\end{array}$ & $\begin{array}{c}-0.026 \\
(0.349)\end{array}$ \\
\hline Government consumption $\left(\mathrm{G} / \mathrm{Y}^{*}\right)$ : & $\begin{array}{c}-0.735 \\
(0.069)\end{array}$ & $\begin{array}{c}-0.944 \\
(0.105)\end{array}$ & $\begin{array}{c}-0.898 \\
(0.107)\end{array}$ & $\begin{array}{c}-0.752 \\
(0.071)\end{array}$ & $\begin{array}{c}-0.753 \\
(0.070)\end{array}$ & $\begin{array}{l}-0.945 \\
(0.114)\end{array}$ \\
\hline --- and large change in surplus & & $\begin{array}{c}0.290 \\
(0.105)\end{array}$ & & & & \\
\hline --- and large increase in surplus & & & $\begin{array}{c}0.395 \\
(0.115)\end{array}$ & & & $\begin{array}{c}0.385 \\
(0.122)\end{array}$ \\
\hline --- and large decrease in surplus & & & $\begin{array}{c}0.187 \\
(0.111)\end{array}$ & & & $\begin{array}{c}0.189 \\
(0.119)\end{array}$ \\
\hline --- and high debt & & & & $\begin{array}{c}0.005 \\
(0.072)\end{array}$ & & $\begin{array}{c}-0.007 \\
(0.189)\end{array}$ \\
\hline --- and rapid debt growth & & & & & $\begin{array}{c}-0.033 \\
(0.175)\end{array}$ & $\begin{array}{c}0.036 \\
(0.296)\end{array}$ \\
\hline Adjusted $R^{2}$ & 0.934 & 0.930 & 0.928 & 0.933 & 0.934 & 0.928 \\
\hline
\end{tabular}


Table 4

\section{Effect of Fiscal Policy on National Saving: World Saving Data Base}

The dependent variable is the ratio of gross national saving to gross national disposable income. The number of developing countries used in the estimation is 101 and the number of observations is 1770 . Net taxes and government consumption refer to the central government only. Estimator: OLS with fixed effects. Standard errors are in parenthesis. The definition of the interaction terms is reported in the text.

\begin{tabular}{|c|c|c|c|c|c|c|}
\hline & (1) & (2) & (3) & (4) & (5) & (6) \\
\hline Lagged national saving rate & $\begin{array}{c}0.459 \\
(0.019)\end{array}$ & $\begin{array}{c}0.460 \\
(0.019)\end{array}$ & $\begin{array}{c}0.467 \\
(0.019)\end{array}$ & $\begin{array}{c}0.457 \\
(0.019)\end{array}$ & $\begin{array}{c}0.459 \\
(0.019)\end{array}$ & $\begin{array}{c}0.466 \\
(0.019)\end{array}$ \\
\hline Output gap & $\begin{array}{c}0.300 \\
(0.017)\end{array}$ & $\begin{array}{c}0.294 \\
(0.017)\end{array}$ & $\begin{array}{c}0.294 \\
(0.017)\end{array}$ & $\begin{array}{c}0.301 \\
(0.017)\end{array}$ & $\begin{array}{c}0.303 \\
(0.017)\end{array}$ & $\begin{array}{c}0.297 \\
(0.017)\end{array}$ \\
\hline Dependency ratio & $\begin{array}{l}-0.228 \\
(0.064)\end{array}$ & $\begin{array}{l}-0.210 \\
(0.064)\end{array}$ & $\begin{array}{l}-0.221 \\
(0.064)\end{array}$ & $\begin{array}{l}-0.216 \\
(0.065)\end{array}$ & $\begin{array}{l}-0.212 \\
(0.064)\end{array}$ & $\begin{array}{c}-0.200 \\
(0.065)\end{array}$ \\
\hline Net taxes $(\mathrm{T} / \mathrm{Y})$ : & $\begin{array}{c}0.257 \\
(0.029)\end{array}$ & $\begin{array}{c}0.456 \\
(0.059)\end{array}$ & $\begin{array}{c}0.447 \\
(0.059)\end{array}$ & $\begin{array}{c}0.273 \\
(0.031) \\
\end{array}$ & $\begin{array}{c}0.261 \\
(0.029)\end{array}$ & $\begin{array}{c}0.464 \\
(0.060)\end{array}$ \\
\hline --- and large change in surplus & & $\begin{array}{c}-0.214 \\
(0.056)\end{array}$ & & & & \\
\hline --- and large increase in surplus & & & $\begin{array}{c}-0.168 \\
(0.059) \\
\end{array}$ & & & $\begin{array}{c}-0.175 \\
(0.059) \\
\end{array}$ \\
\hline --- and large decrease in surplus & & & $\begin{array}{c}-0.257 \\
(0.057)\end{array}$ & & & $\begin{array}{c}-0.252 \\
(0.057)\end{array}$ \\
\hline --- and high debt & & & & $\begin{array}{c}-0.129 \\
(0.081)\end{array}$ & & $\begin{array}{c}-0.106 \\
(0.081)\end{array}$ \\
\hline --- and rapid debt growth & & & & & $\begin{array}{c}-0.301 \\
(0.104)\end{array}$ & $\begin{array}{l}-0.260 \\
(0.104)\end{array}$ \\
\hline Government consumption $(\mathrm{G} / \mathrm{Y})$ : & $\begin{array}{c}-0.493 \\
(0.039) \\
\end{array}$ & $\begin{array}{c}-0.716 \\
(0.070)\end{array}$ & $\begin{array}{c}-0.691 \\
(0.070)\end{array}$ & $\begin{array}{c}-0.502 \\
(0.039) \\
\end{array}$ & $\begin{array}{c}-0.497 \\
(0.039) \\
\end{array}$ & $\begin{array}{c}-0.701 \\
(0.071) \\
\end{array}$ \\
\hline --- and large change in surplus & & $\begin{array}{c}0.248 \\
(0.065)\end{array}$ & & & & \\
\hline --- and large increase in surplus & & & $\begin{array}{c}0.232 \\
(0.070)\end{array}$ & & & $\begin{array}{c}0.242 \\
(0.071)\end{array}$ \\
\hline --- and large decrease in surplus & & & $\begin{array}{c}0.264 \\
(0.067)\end{array}$ & & & $\begin{array}{c}0.257 \\
(0.067)\end{array}$ \\
\hline --- and high debt & & & & $\begin{array}{c}0.171 \\
(0.098)\end{array}$ & & $\begin{array}{c}0.133 \\
(0.099)\end{array}$ \\
\hline --- and rapid debt growth & & & & & $\begin{array}{c}0.252 \\
(0.111)\end{array}$ & $\begin{array}{c}0.203 \\
(0.112) \\
\end{array}$ \\
\hline Adjusted $R^{2}$ & 0.815 & 0.816 & 0.819 & 0.815 & 0.816 & 0.819 \\
\hline
\end{tabular}




\section{Table 5}

\section{Effect of Fiscal Policy on National Saving: World Saving Data Base with Higher Thresholds for the Identification of Fiscal Episodes}

The "limit" refers to the percentage change in the surplus over a two-year period used to define fiscal episodes. The dependent variable is the ratio of gross national saving to gross national disposable income. The number of developing countries is 101 and the number of observations is 1770 . Net taxes and government consumption refer to the central government only. See text for the definition of the interaction terms. Estimator: OLS with fixed effects. Standard errors are in parenthesis. The definition of the interaction terms is reported in the text.

\begin{tabular}{|l|c|c|c|c|}
\hline & \multicolumn{2}{|c|}{ Limit is 2.5 percent } & \multicolumn{2}{c|}{ Limit is 5 percent } \\
\hline & $\mathbf{( 1 )}$ & $\mathbf{( 2 )}$ & $\mathbf{( 3 )}$ & $\mathbf{( 4 )}$ \\
\hline Lagged national saving rate & 0.469 & 0.468 & 0.468 & 0.467 \\
& $(0.019)$ & $(0.019)$ & $(0.019)$ & $(0.019)$ \\
\hline Output gap & 0.296 & 0.299 & 0.293 & 0.297 \\
& $(0.017)$ & $(0.017)$ & $(0.017)$ & $(0.017)$ \\
\hline Dependency ratio & -0.213 & -0.195 & -0.209 & -0.193 \\
& $(0.064)$ & $(0.065)$ & $(0.064)$ & $(0.065)$ \\
\hline Net taxes (T/Y): & 0.381 & 0.389 & 0.324 & 0.330 \\
& $(0.048)$ & $(0.049)$ & $(0.041)$ & $(0.042)$ \\
\hline--- and large increase in surplus & -0.098 & -0.098 & -0.047 & -0.046 \\
& $(0.049)$ & $(0.050)$ & $(0.045)$ & $(0.045)$ \\
\hline --- and large decrease in surplus & -0.213 & -0.202 & -0.157 & -0.145 \\
& $(0.048)$ & $(0.048)$ & $(0.043)$ & $(0.043)$ \\
\hline --- and high debt & & -0.084 & & -0.074 \\
& & $(0.081)$ & & $(0.082)$ \\
\hline--- and rapid debt growth & & -0.255 & & -0.266 \\
& & $(0.105)$ & & $(0.105)$ \\
\hline Government consumption (G/Y): & -0.632 & -0.636 & -0.548 & -0.551 \\
& $(0.060)$ & $(0.060)$ & $(0.051)$ & $(0.051)$ \\
\hline--- and large increase in surplus & 0.148 & 0.152 & 0.049 & 0.051 \\
& $(0.061)$ & $(0.062)$ & $(0.059)$ & $(0.059)$ \\
\hline--- and large decrease in surplus & 0.231 & 0.217 & 0.143 & 0.129 \\
& $(0.058)$ & $(0.058)$ & $(0.052)$ & $(0.052)$ \\
\hline--- and high debt & & 0.100 & & 0.079 \\
& & $(0.099)$ & & $(0.100)$ \\
\hline--- and rapid debt growth & 0.204 & & 0.220 \\
& & $(0.112)$ & & $(0.113)$ \\
\hline \multirow{2}{*}{ Adjusted $R^{2}$} & & 0.818 & & 0.817 \\
\hline
\end{tabular}




\section{Figure 1}

\section{The Non-Linear Relation between Full Employment Surplus and National Saving OECD Countries (1970-96)}

The figure plots the change in the gross national saving rate and the change in the full-employment government surplus (both scaled by full-employment output). In the scatter diagram we draw the fitted values of a linear spline regression of changes in national saving on changes in full employment surplus with knots set for values of the fullemployment surplus equal to -1.5 and 1.5 percent (marked by the two vertical segments).

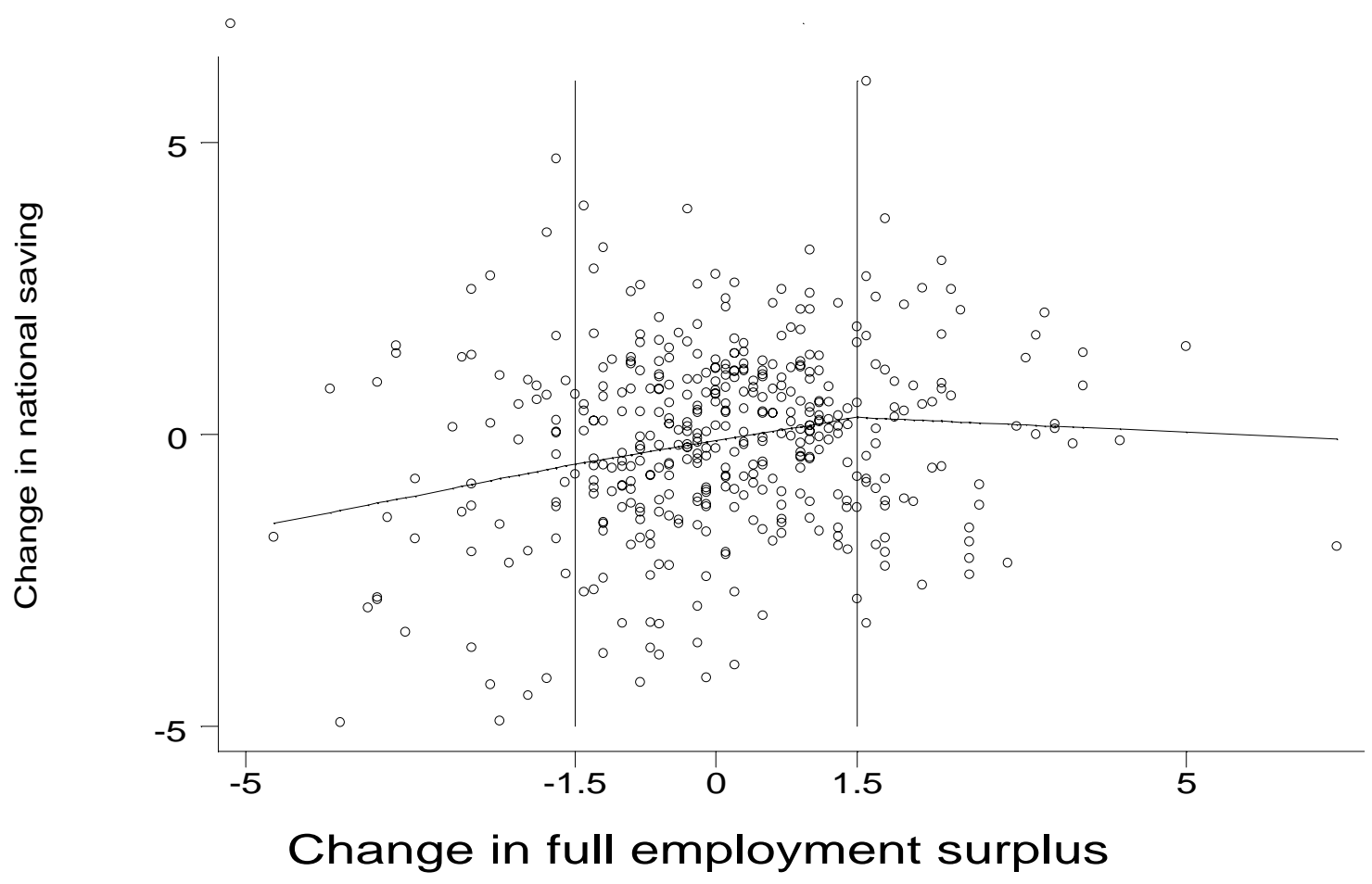




\section{Figure 2}

\section{The Effect of Government Surplus on National Saving in Selected Countries}

The figure plots the actual ratio of the national saving rate to potential output and the estimated effect of the ratio of government surplus to potential output on national saving in Sweden, Denmark, Ireland, and Belgium. For each country, the national saving rate is plotted in deviations from its mean. To compute the effect of the surplus, we use the coefficients estimated in column 3 of Table 3. The line marked with diamonds is the national saving rate, the line marked with circles is the effect of the deficit in normal times, and the line marked with crosses the total effect of the deficit.
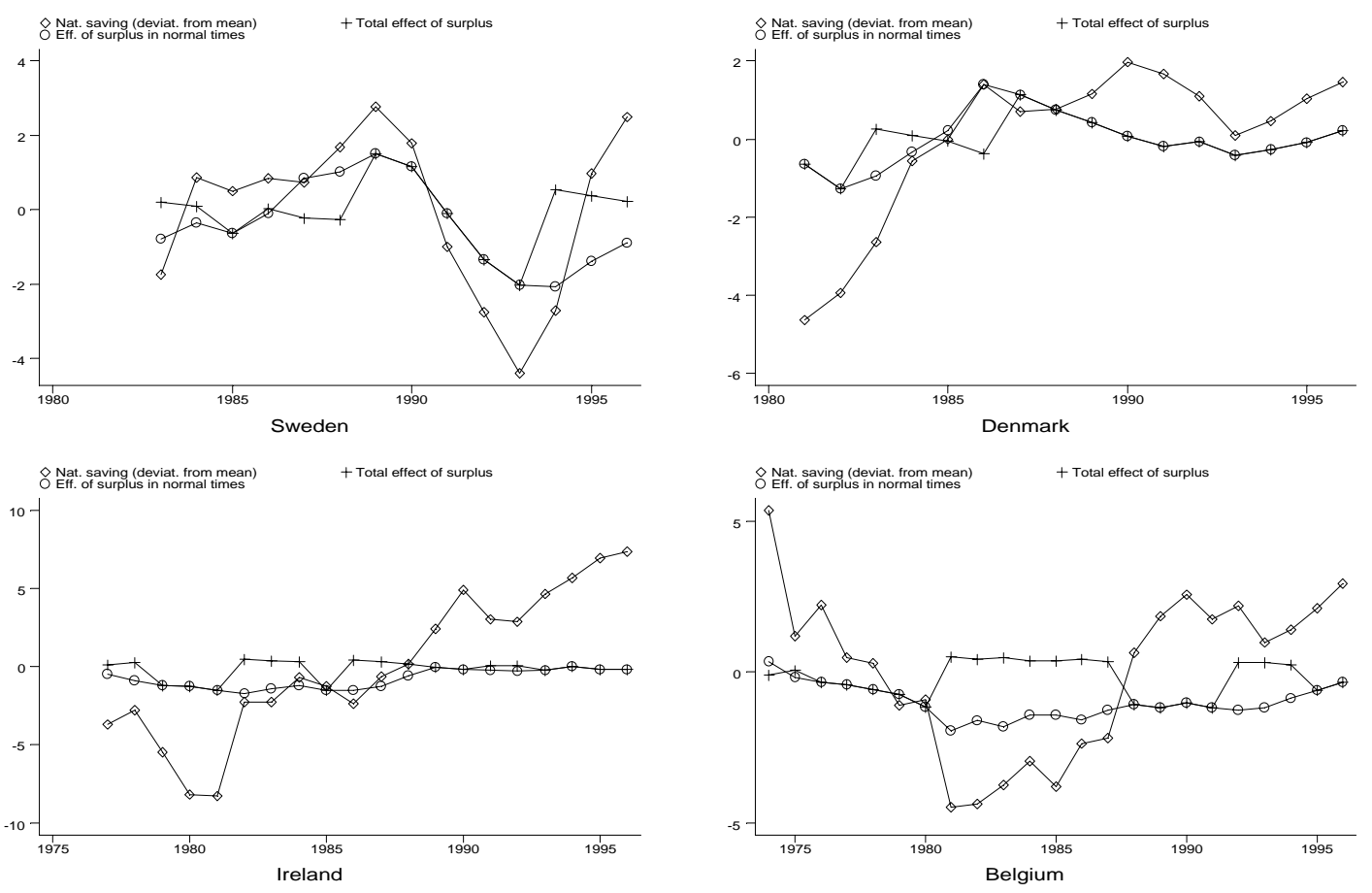


\section{Appendix}

\section{Definition of the Variables: OECD data}

All data are drawn from the OECD Economic Outlook database published in June 1997. Public sector data refer to general government.

\begin{tabular}{|l|c|}
\hline \multicolumn{1}{|c|}{ Variable } & OECD Series \\
\hline Private consumption & CP \\
\hline Government consumption & CG \\
\hline Government savings & SAVG \\
\hline Government debt & GGFL \\
\hline Gross National/Domestic Product & GDPV \\
\hline Deflator for consumer expenditure & PCP \\
\hline Taxes net of transfers & SAVG+CG \\
\hline Government investment & IG \\
\hline Social security contributions & SS \\
\hline Social security benefits & SSPG \\
\hline Full employment government surplus & NLQGA \\
\hline Potential output & GDPVTR \\
\hline
\end{tabular}

\section{Countries and Sample Period Used in the Estimation: OECD data}

\begin{tabular}{|l|c|l|l|}
\hline \multicolumn{1}{|c|}{ Country } & Sample Period & \multicolumn{1}{c|}{ Fiscal Expansions } & \multicolumn{1}{c|}{ Fiscal Contractions } \\
\hline Australia & $1973-96$ & $83-84 ; 90-92$ & $73-74 ; 76-77 ; 80-82 ; 86-88 ; 95-96$ \\
\hline Austria & $1974-96$ & $93-94$ & $74-75 ; 77-78 ; 80-81 ; 83-85 ; 95-96$ \\
\hline Belgium & $1974-96$ & $79-80$ & $74-75 ; 81-87 ; 92-94$ \\
\hline Canada & $1973-96$ & $75-76 ; 82-85$ & $73-74 ; 80-81 ; 86-87 ; 94-96$ \\
\hline Denmark & $1981-96$ & $81-82 ; 87-90$ & $83-86$ \\
\hline Finland & $1973-96$ & $77-80 ; 82-83 ; 86-87 ; 90-92$ & $73-76 ; 84-85 ; 88-89 ; 93-96$ \\
\hline France & $1972-96$ & $77-78 ; 81-82$ & $72-73 ; 79-80 ; 83-84 ; 95-96$ \\
\hline Germany & $1970-96$ & $74-75 ; 89-91$ & $71-72 ; 76-77 ; 81-83 ; 92-94$ \\
\hline Greece & $1975-96$ & $80-81 ; 84-85 ; 88-89$ & $75-76 ; 82-83 ; 86-87 ; 90-96$ \\
\hline Ireland & $1977-96$ & $89-90 ; 94-95$ & $77-78 ; 82-84 ; 86-88 ; 91-92$ \\
\hline Italy & $1972-96$ & $74-75 ; 78-79 ; 84-85$ & $72-73 ; 76-77 ; 82-83 ; 92-96$ \\
\hline Japan & $1972-96$ & $75-79 ; 92-94$ & $72-74 ; 80-85$ \\
\hline Netherlands & $1974-96$ & $76-80 ;$ & $74-75 ; 81-83 ; 87-88 ; 90-92$ \\
\hline Portugal & $1970-96$ & $72-76 ; 80-81 ; 89-90$ & $70-71 ; 82-86 ; 91-92 ; 94-95$ \\
\hline Spain & $1970-96$ & $81-82 ; 89-90$ & $86-87 ; 91-93 ; 95-96$ \\
\hline Sweden & $1983-96$ & $90-93$ & $83-84 ; 86-88 ; 94-96$ \\
\hline United Kingdom & $1970-96$ & $72-74 ; 83-84 ; 91-93$ & $70-71 ; 79-82 ; 89-90 ; 94-96$ \\
\hline United States & $1970-96$ & $74-75 ; 82-83$ & $70-71 ; 76-77 ; 94-95$ \\
\hline
\end{tabular}




\section{Definition of the Variables: World Saving Data Base}

Data can be downloaded from ftp://monarch/worldbank.org/pub/prddr/outbox. Public sector data refer to central government. A detailed description of the data set can be found in Loayza et al. (1998). The database includes 150 countries and spans the years 1960 to 1995 . However, not all variables are available for every country every year. Hence the effective time coverage of the data files varies substantially across modules and, within a given module, across countries and variables. National Saving is defined inclusive of all external transfers. The consumption figures include any statistical discrepancies present in the GDP expenditure identity. Gross National Disposable Income (GNDI) is defined as GNP + External transfers; Gross National Saving is defined as GNDI - Total Consumption. The definition of the public sector is that of consolidated central government, i.e. budgetary central government plus extra-budgetary central government plus social security agencies. This definition thus excludes local and regional governments. Each series consists of an Excel 5.0 file; the files we have used are given in the table below.

\begin{tabular}{|l|c|}
\hline \multicolumn{1}{|c|}{ Variable } & File \\
\hline Gross National Disposable Income (GNDI) & FORMU334.XLS \\
\hline Private consumption & FORMU21.XLS \\
\hline Government consumption & FORMU23.XLS \\
\hline Gross national saving & FORMU333.XLS \\
\hline Government savings / GNDI & FORMU342.XLS \\
\hline Taxes net of transfers & Fovernment saving + government consumption \\
\hline Government debt / GNDI & FORMU16.XLS \\
\hline GDP at current prices & FORMU17.XLS \\
\hline GDP at 1987 prices & CONST263.XLS \\
\hline Total population & CONST264.XLS \\
\hline Population younger than 15 & CONST265.XLS \\
\hline Population older than 65 & FORMUS \\
\hline
\end{tabular}

